\title{
SRS Process Facility Significance Fire Frequency
}

by

A. G. Sarrack

Westinghouse Savannah River Company

Savannah River Site

Aiken, South Carolina 29808
- RECEIVED

JUN 111998

Q.STI

This paper was prepared in connection with work done under the above contract number with the U.S. Department of Energy. By acceptance of this paper, the publisher and/or recipient acknowledges the U.S. Government's right to retain a nonexclusive, royalty-free license in and to any copyright covering this paper, along with the right to reproduce and to authorize others to reproduce all or part of the copyrighted paper.

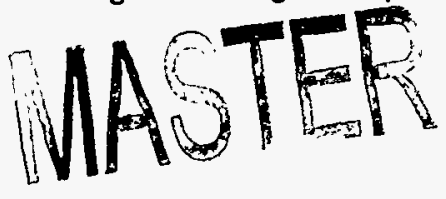

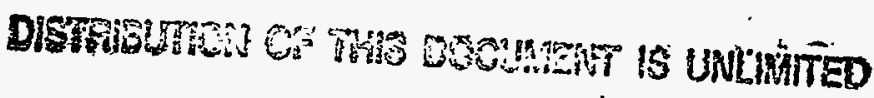




\section{$7 / 6893$ \\ WSRC-TR-95-0389 \\ SAFETY ENGINEERING DEPARTMENT}

\section{SRS PROCESS FACUITY SIGNIFTCANT FIRE FREQUENCY (U)}

\section{AG Sarrack}

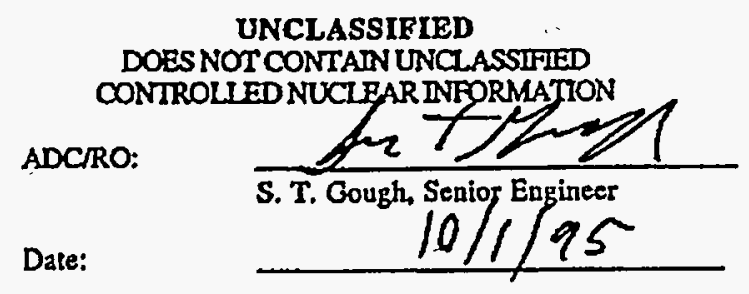

Westinghouse Savannah River Company

Safety Englneering Division *

Alken, SC 29808

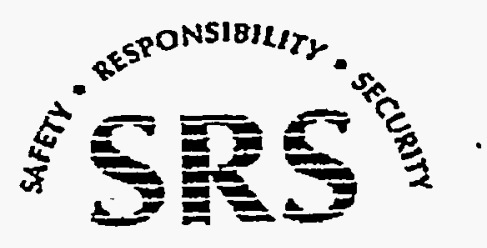




\section{DISCLAIMER}

This report was prepared as an account of work sponsored by an agency of the United States Government. Neither the United States Government nor any agency thereof, nor any of their employees, makes any warranty, express or implied, or assumes any legal liability or responsibility for the accuracy, completeness, or usefulness of any information, apparatus, product, or process disclosed, or represents that its use would not infringe privately owned rights. Reference herein to any specific commercial product, process, or service by trade name, trademark, manufacturer, or otherwise does not necessarily constitute or imply its endorsement, recommendation, or favoring by the United States Government or any agency thereof. The views and opinions of authors expressed herein do not necessarily state or reflect those of the United States Government or any agency thereof.

This report has been reproduced directly from the best available copy.

Available to DOE and DOE contractors from the Office of Scientific and Technical Information, P. O. Box 62, Oak Ridge, TN 37831; prices available from (423) 576-8401.

Available to the public from the National Technical Information Service, U. S. Department of Commerce, 5285 Port Royal Road, Springfield, VA 22161. 


\section{DISCLAIMER}

Portions of this document may be illegible electronic image products. Images are produced from the best available original document. 


$\begin{array}{ll}\text { KEYWORDS: } & \text { Fire } \\ & \text { SRS } \\ & \text { Process } \\ & \text { Frequency } \\ & \text { Initiator }\end{array}$

SRS PROCESS FACILITY SIGNIFICANT FIRE FREQUENCY (U)

AG Sarrack

Issued: October, 1995

Approyals:

AG Sarrack, Ruthor

$\frac{9-28-95}{\text { Date }}$

Risk Assessment Group

IS (rames

DS Cramer, Technical Reviewer

Safety Information Management Analysis Group

202 hos?

DA Sharp, Manager

Initiator

Risk Assessment Group

MPHitchler, Manager

Strety Analysis Engineering Section
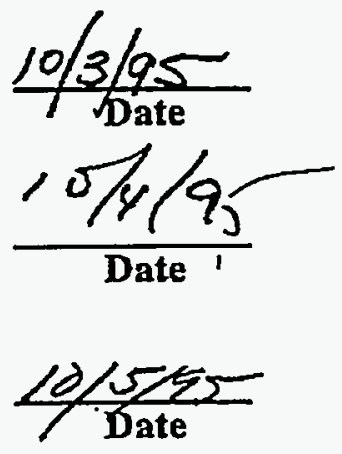

Westinghouse Savannah RIver Company

Safety Engineering Division

Alken, SC 29808

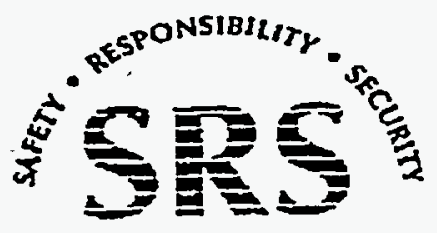




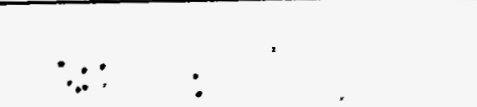

:

THIS PAGE INTENTIONALLY LEFT BLANK

: 


\section{ABSTRACT:}

Accidents caused by fire are anlyzed for each SRS facility Safety Analysis Report. These analyses are based on an initiation frequency and the probability that mitigative systems or actions will control the fire. Because SRS process facilities are designed similarly (from a fire protection point of view), and use similar fire prevention and mitigation procedures, it is reasonable to develop a site generic process facility significant fire initiator frequency, and apply it to all SRS process facilities.

This report documents the method and assumptions of a study performed to determine a site generic process facility significant fire initiator frequency and explains the proper way this value should be used. 


\subsection{INTRODUCTION}

Risk analysis is used to determine the risk due to fire for a given facility. The risk of a fire is defined as the expected frequency of a fire multiplied by the consequence of that fire. Because the frequency of fires (any size) within a facility is fairly high (on the order of 1 per year), and the potential consequences range from insignificant to full facility loss, fire accidents are grouped by severity, and each case is evaluated separately. The facility fire risk is the sum of each fire group risk.

According to SRS historical data (Reference 1), the majority of process facility fires are detected early and extinguished before significant damage occurs. These fires are typically selfextinguishing or are extinguished by facility occupants with fire extinguishers. These events have no significant consequence and need not be included in the fire initiator frequency when performing fire risk calculations. Similarly, fires that are controlled by the fire department using only hand-held fire extinguishers occur fairly regularly (once every few years for an average process facility), but have no consequences, and are not included as significant fires.

The purpose of this report is to document the results of a study that determines the frequency of significant fires in SRS process facilities, based on recent historical SRS process facility fire data. SRS process facilities are facilities identified in Table 1. Significant fires are defined as fires that challenge an automatic suppression system, or are extinguished by the fire department, using more than hand-held fire extinguishers.

\subsection{METHOD}

\subsection{Assumptions and Definitions}

1. "Recent, significant, process facility fire events" are fires reported in the SRS data base (Reference 1) with the following characteristics:

a. Occurred between $1 / 1 / 75$ and 9/20/95

b. Occurred inside of a process facility listed in Table 1

c. Extinguished by automatic suppression system or by the fire department, using more than hand-held fire extinguishers.

2. Fire frequencies for process facilities prior to $\mathbf{1 9 7 5}$ may not reflect current conditions and are not included in this calculation.

3. Fire frequencies in facilities that are in "shutdown" may not reflect fire frequencies of operating process facilities and are not included in this calculation.

4. Fire frequencies of testing facilities ( $T$-area facilities) may not reflect fire frequencies of process facilities and are not included in this calculation. 
WSRC-TR-95-0389

Revision 0

\subsection{Input Data}

1. SRS fire event data base (Reference 1)

2. List of all SRS facilities, sizes, years of operation (Reference 2)

3. List of SRS process facilities (Table 1)

\subsection{Analytical Methods and Computations}

An outline of the steps taken to determine the frequency of SRS process facility fires, followed by a detailed description of each step follows:

\section{Outline}

1. Compile list of all SRS facilities of interest (process facilities)

a. Use Benefit vs Cost Evaluation document (Reference 2) as starting point (includes all facilities, as of 1990)

b. Delete all non-process facilities (using list of process facilities in Table 1)

c. Add new process facilities (ones started since 1990)

2. Compile list of fires in process facilities
a. Start with site fire database (Reference 1) on Filemaker Pro (includes all SRS fire events, from 1958 to present)
b. Download to Microsoft Word
c. Sort by date, and delete events prior to 1975
d. Sort by building numbers, and delete all entries that are not process facilities
e. Delete entries that are entered as process facilities but are described within the entry as not really within facility (delete fires near facilities)

3. Catėgorize fires into "controlled" or "significant fire event."

4. Create spreadsheet of process facilities, histories, calculated frequencies
a. Enter facilities from item 1 above.
b. Add total floor space for each facility
c. Enter applicable operating years for each facility
d. Enter number of significant fires for each facility
e. Calculate facility "area-years" for each facility
f. Calculate the significant fire frequency 


\section{Details of each step}

1a. Get a list of all SRS facilities (including sizes) from the 1992 Benefit vs Cost Evaluation document (Reference 2). This document reflects data from 1958 through 1990.

1b. Delete facilities that are not process facilities. The objective of this calculation is to document a fire frequency for process facilities. There is adequate volume of data from SRS process facilities making it is unnecessary to include non-process facilities, which may have dissimilar fire initiation frequencies. TNX is deleted because the type of operations in those facilities is more testing and less production, which may experience significantly different fire initiation frequencies.

1c. Add process facilities that are not included in Reference 2. RTF has been added to this table because it has begun radioactive operations since Reference 2 was issued. DWPF and CIF are left out, since they have not yet accumulated appropriate operational data.

The resulting facility list is presented in column 1 of Table 1.

2a. Copy the current version of SRS fire events, as of 9-20-95 (Reference 1). This data base is maintained by the Criticality \& Fire Analysis Section (C\&FAS) of the Engineering \& Construction Services Division (E\&CSD). At the time that the data hase was copied for this calculation, 1,227 SRS fire events were included.

2b. The data base (a File Maker Pro file) allows data to be downloaded to a Microsoft Word file. The following fields were included in the transfer of data base information into Microsoft Word:

Date - Date of the event

Building - Building that fire affected

Area - Area of SRS where fire occurred

Description - Description of fire progression, usually including the cause, the extent of damage, and the method of extinguishment.

2c. Once SRS fire event data is in Microsoft Word, the file is sorted by the "date" column. All rows (events) prior to 1/1/75 are deleted. This is because recent operational data is expected to be more representative of future experience than older data. There is no specific reason for choosing 1975 as a starting point. The objective is to eliminate older data without deleting so much that there are not enough significant events to remain statistically accurate.

2d. Re-sort the table, this time using the "building" column. All rows (events) under facilities that are not included in Table 1 are deleted. This removes fire events that are in office buildings, warehouses, storage buildings, trailers, and other facilities that are not similar to typical process facilities.

2e. Read descriptions of euch remaining event. Delete rows (events) that are described as being . outside the facility. Some of these events are vehicle fires (in vehicles parked near a process facility) or in dumpsters outside the facility.

Following step 2, the remaining events are recent process facility fires. These events are presented in Appendix 1. 
3. Categorize Appendix 1 fire events into "controlled" or "significant fire event." Identify as "controlled" if fire was self-extinguished, extinguished by facility worker, or extinguished by fire department using fire extinguisher. Identify as "significant fire event" if fire was extinguished by automatic suppression system, or if it was extinguished by the fire department, using more than hand held fire extinguishers.

Following step 3, the remaining events are significant, recent process facility fires. These events are presented in Appendix 2. (This is a subset of Appendix 1.)

4a. Using the list of process facilities in Table 1, create a list of process facilities in a column of an Excel spreadsheet. This list may include some facilities not in the fire data base because some facilities may have no recorded fire events (such as RTF).

4b. From Reference 2, enter the approximate square footage of each facility in the second column. Use of these values assumes that fire frequency in a given facility is proportional to the floor area of that facility. It is not critical that these numbers be exact, only that they are the right order of magnitude. It is conservative to under estimate the size of facilities for this part of the calculation.

4c. In the third and fourth columns enter each facility's startup date (or 1/1/75 if started earlier than that) and shutdown date (or $9 / 20 / 95$, if the facility is still pperating). Use the next column to calculate the years of operation. The years of operation are necessary to convert the number of fires to a frequency.

4d. Using the data from step 3 above, enter the number of significant fire events for each facility in column 7 . It is not expected that there will be very many of these events, because as stated earlier, most fires at SRS have been extinguished by facility occupants or fire department personnel while the fire is still in the incipient or early growth stage.

4e. Calculate facility "area-years" for each facility by using column 8, entering the product of column 2 (facility square fontage) and column 5 (facility years of operation). The sum bf all facility "area -years" is calculated by adding all entries in column 8.

4f. Calculate the average SRS process facility significant fire event frequency by dividing the total number of significant fires by the sum of facility "area-years" (from step 4e). This is the site generic value for significant fires in process facilities at SRS (per year, per square foot).

The result of step $4 \mathrm{f}$ is the value of interest for this calculation. This number represents the frequency at which a fire is expected (per square foot) in an SRS process facility, such as RTF, reactors, DWPF, or the separation facilities. 


\section{Table 1}

SRS Process Facility Sizes, Years of Operation, and \# of Significant Fires

\begin{tabular}{|c|c|c|c|c|c|c||}
\hline BLDG & SQ FT & $\begin{array}{c}\text { Date } \\
\text { started }\end{array}$ & $\begin{array}{c}\text { Date } \\
\text { Shutdown }\end{array}$ & $\begin{array}{c}\text { Years of } \\
\text { operation }\end{array}$ & $\begin{array}{c}\text { Area-years of } \\
\text { operation }\end{array}$ & $\begin{array}{c}\text { Significant } \\
\text { fires }\end{array}$ \\
\hline $105-\mathrm{C}$ & 500,000 & $01 / 01 / 75$ & $12 / 01 / 88$ & 13.9 & $7.0 \mathrm{E}+06$ & 0 \\
\hline $105-\mathrm{K}$ & 500,000 & $01 / 01 / 75$ & $12 / 01 / 88$ & 13.9 & $7.0 \mathrm{E}+06$ & 0 \\
\hline $105-\mathrm{L}$ & 500,000 & $10 / 01 / 85$ & $12 / 01 / 88$ & 3.2 & $1.6 \mathrm{E}+06$ & 0 \\
\hline $105-\mathrm{P}$ & 750,000 & $01 / 01 / 75$ & $12 / 01 / 88$ & 13.9 & $1.0 \mathrm{E}+07$ & 0 \\
\hline $108-1 \mathrm{C}$ & 6,000 & $01 / 01 / 75$ & $12 / 01 / 88$ & 13.9 & $8.4 \mathrm{E}+04$ & 0 \\
\hline $108-1 \mathrm{~L}$ & 6,000 & $10 / 01 / 85$ & $12 / 01 / 88$ & 3.2 & $1.9 \mathrm{E}+04$ & 0 \\
\hline $108-1 \mathrm{P}$ & 6,000 & $01 / 01 / 75$ & $12 / 01 / 88$ & 13.9 & $8.4 \mathrm{E}+04$ & 0 \\
\hline $108-2 \mathrm{C}$ & 6,000 & $01 / 01 / 75$ & $12 / 01 / 88$ & 13.9 & $8.4 \mathrm{E}+04$ & 0 \\
\hline $108-2 \mathrm{~K}$ & 6,000 & $01 / 01 / 75$ & $12 / 01 / 88$ & 13.9 & $8.4 \mathrm{E}+04$ & 0 \\
\hline $108-2 \mathrm{~L}$ & 6,625 & $10 / 01 / 85$ & $12 / 01 / 88$ & 3.2 & $2.1 \mathrm{E}+04$ & 0 \\
\hline $108-2 \mathrm{P}$ & 6,000 & $01 / 01 / 75$ & $12 / 01 / 88$ & 13.9 & $8.4 \mathrm{E}+04$ & 0 \\
\hline $221-1 \mathrm{~F}$ & 24,067 & $01 / 01 / 75$ & $09 / 20 / 95$ & 20.7 & $5.0 \mathrm{E}+05$ & 0 \\
\hline $221-\mathrm{F}$ & 329,600 & $01 / 01 / 75$ & $09 / 20 / 95$ & 20.7 & $6.8 \mathrm{E}+06$ & 3 \\
\hline $221-\mathrm{H}$ & 329,600 & $01 / 01 / 75$ & $09 / 20 / 95$ & 20.7 & $6.8 \mathrm{E}+06$ & 1 \\
\hline $232-1 \mathrm{H}$ & 11,000 & $01 / 01 / 75$ & $09 / 20 / 95$ & 20.7 & $2.3 \mathrm{E}+05$ & 0 \\
\hline $232-\mathrm{F}$ & 16,440 & $01 / 01 / 75$ & $09 / 20 / 95$ & 20.7 & $3.4 \mathrm{E}+05$ & 0 \\
\hline $232-\mathrm{H}$ & 55,220 & $01 / 01 / 75$ & $09 / 20 / 95$ & 20.7 & $1.1 \mathrm{E}+06$ & 0 \\
\hline $233-\mathrm{H}$ & 40,000 & $01 / 01 / 94$ & $09 / 20 / 95$ & 1.7 & $6.9 \mathrm{E}+04$ & 0 \\
\hline $234-\mathrm{H}$ & 45,737 & $01 / 01 / 75$ & $09 / 20 / 95$ & 20.7 & $9.5 \mathrm{E}+05$ & 0 \\
\hline $235-\mathrm{F}$ & 47,080 & $09 / 01 / 84$ & $09 / 20 / 95$ & 11.1 & $5.2 \mathrm{E}+05$ & 1 \\
\hline $235-\mathrm{H}$ & 12,000 & $01 / 01 / 75$ & $09 / 20 / 95$ & 20.7 & $2.5 \mathrm{E}+05$ & 0 \\
\hline $247-\mathrm{F}$ & 140,000 & $07 / 01 / 88$ & $09 / 20 / 90$ & 2.2 & $3.1 \mathrm{E}+05$ & 0 \\
\hline $313-\mathrm{M}$ & 57,212 & $01 / 01 / 75$ & $09 / 20 / 95$ & 20.7 & $1.2 \mathrm{E}+06$ & 0 \\
\hline $320-\mathrm{M}$ & 63,288 & $01 / 01 / 75$ & $09 / 20 / 95$ & 20.7 & $1.3 \mathrm{E}+06$ & 1 \\
\hline $321-\mathrm{M}$ & 56,072 & $01 / 01 / 75$ & $09 / 20 / 95$ & 20.7 & $1.2 \mathrm{E}+06$ & 1 \\
\hline $773-\mathrm{A}$ & 304,000 & $01 / 01 / 75$ & $09 / 20 / 95$ & 20.7 & $6.3 \mathrm{E}+06$ & $\cdot 1 * 1$ \\
\hline Totals & $\mathrm{NA}$ & $\mathrm{NAA}$ & $\mathrm{NA}$ & $\mathrm{NA}$ & $5.4 \mathrm{E}+07$ & 8 \\
\hline
\end{tabular}

*1 Note that two events that occurred in 773-A were deleted (as shown by strikethrough lettering in Appendix 2), based on being welding events. It is believed that these events would have been controlled by a facility employee, if no automatic suppression system or fire department response were provided.

SRS process facility significant fire frequency

$=8$ fires $/ 5.4 \times 10^{7} \mathrm{ft}^{2}$ years

$=1.5 \times 10^{-7}$ fires per $\mathrm{ft}^{2}$ per year 


\subsection{Results and Conclusion}

Analysis of recent SRS fire historical data leads the conclusion that significant fires in SRS process facilities occur at a rate of $1.5 \times 10^{-7}$ per $\mathrm{ft}^{2}$ per year. This value is multiplied by the size (square footage) of the process facility of interest to give the expected frequency of significant fire events for that facility. Examples of facilities, sizes, and corresponding fire frequencies follow:

\begin{tabular}{lcc} 
Eacility & $\begin{array}{c}\text { Facility } \\
\text { Size (ft. 2) }\end{array}$ & $\begin{array}{c}\text { Expected Fire } \\
\text { Erequency (peryear) }\end{array}$ \\
\hline $233-\mathrm{H}$ & 40,000 & $6 \times 10^{-3}$ \\
$234-\mathrm{H}$ & 45,800 & $7 \times 10^{-3}$ \\
$221-\mathrm{S}$ & 192,000 & $3 \times 10^{-2}$
\end{tabular}

When using the significant process facility fire frequency value for facility fire risk calculations, caution must be used to ensure that additional credit is not given to facility response or fire department response to small fires because these mitigating factors are inherently credited within the derivation of this number. In addition, if a process facility plans to operate with less procedural controls that prevent or mitigate fires than have been used in the past, this value may not be valid.

\subsection{REFERENCES}

1. MD Brandyberry, Analysis of SRS Fire Records (U), WSRC-RP-90-143, Revision 0, March 12, 1990.

Note: Reference 1 was developed in 1990 and is maintained current by the Fire Protection group of $E \& C S D$, based on monthly fire reports.

2. HA Ford, DF Paddleford, MJ Vitacco, Benefit vs. Cost Evaluation Methodology for Fire Protection Upgrade Projects (U), WSRC-TR-92-141, Revision 0, May 1992. 


\section{APPENDIX 1: DATA BASE FIRE EVENTS SINCE 1/1/1975}

\begin{tabular}{|c|c|c|c|}
\hline $\cos (1) x$ & Are: & Date & Description of event \\
\hline 105 & $\mathrm{p}$ & $9 / 18 / 86$ & $\begin{array}{l}\text { A FIRE OCCURRED IN 105-P, +15 LUNCHROOM, WHEN JUICE FROMMEAT FELL ON A } \\
\text { BURNER AND IGNITED. THE FIRE WAS EXTINGUISHED WITH BAKNG SODA. NO } \\
\text { DAMAGE. }\end{array}$ \\
\hline 105 & $P$ & $6 / 13 / 86$ & $\begin{array}{l}\text { A FIRE WAS DISCOVERED IN THE TRASH CONTAINER IN BUILDING 105-P, } 0 \text { LEVEL } \\
\text { LADIES CHANGE ROOM. THE FIRE WAS CAUSED BY DISCHARGED SMOKING MATERIAL } \\
\text { AND WAS EXTINGUISHED BY AN EMPLOYEE. NO DAMAGE. }\end{array}$ \\
\hline 105 & $\mathrm{~L}$ & $10 / 2 / 84$ & $\begin{array}{l}\text { A FIRE OCCURRED IN BUILDING 105-L ROD EQUIPMENT ROOM. THE FIRE WAS CAUSED } \\
\text { WHEN A TRANSFORMER OVERHEATED AND IGNITED. THE FIRE WAS EXTINGUISHED } \\
\text { BY A HALON EXTINGUISHER DAMAGE WAS SIOO. }\end{array}$ \\
\hline 105 & $\mathrm{~K}$ & $11 / 23 / 83$ & $\begin{array}{l}\text { A FIRE OCCURRED ON A FORKLIFT IN BUILDING 105-K WHEN THE CONTACTS BECAME } \\
\text { OVERHEATED. THE FIRE WAS EXITNGUISHED BY AN EMPLOYEE, AND THE FORKLIFT } \\
\text { SUSTAINED ONLY MINOR DAMAGE TO THE WIRING. }\end{array}$ \\
\hline 105 & P & $2 / 23 / 83$ & $\begin{array}{l}\text { A FIRE OCCURRED IN 903-A FAN IN BUILDING 105-P. THE MOTOR OVERHEATED AND } \\
\text { FLAMED UP. THE FIRE WAS EXTTNGISHED BY AN EMPLOYEE. DAMAGE TO FAN IS } \\
\text { UNKNOWN AT THIS TIME }\end{array}$ \\
\hline 105 & $\bar{K}$ & $8 / 6 / 77$ & $\begin{array}{l}\text { FIRE OCCURRED IN A BRAKE COIL OF A CRANE IN THE PURIFICATION AREA OF } 105-\mathrm{K} \text {. } \\
\text { THE FRRE WAS EXIINGUISHED BY AN EMPLOYEE. BELIEVED THAT FIRE STARTED } \\
\text { FROM AN ELECTRICAL SHORT IN THE COIL, DAMAGE WAS LIMITED TO THE COIL. }\end{array}$ \\
\hline 105 & C & $9 / 6 / 75$ & $\begin{array}{l}\text { FIRE OCCURRED IN THE FAN ROOM AT THE +48 FT. LEVEL. EXTINGUISHED BY THE } \\
\text { AREA BRIGADE AND FIRE DIVISION PERSONNEL. }\end{array}$ \\
\hline 105 & $\bar{K}$ & $02 / 20 / 90$ & $\begin{array}{l}\text { A PORTABLE KEROSENE HEATER CAUGHT FIRE IN } 105-K \text { STACK AREA. THE CAUSE OF } \\
\text { THE FIRE IS UNDER NNVESTIGATION. THE FIRE WAS EXTINGUISHED BY AN EMPLOYEE. }\end{array}$ \\
\hline 105 & $\bar{P}$ & $08 / 15 / 90$ & $\begin{array}{l}\text { A FIRE OCCURRED IN BUILDING 105-P TRANSFORMER ROOM \#3 LIGHIING PANEL 33-M. } \\
\text { THE FIRE WAS CAUSED WHEN A FUSE BLEW IN THE LIGHTING PANEL. THE FIRE WAS } \\
\text { EXTINGUISHED WHEN THE POWER WAS CUT OFF. }\end{array}$ \\
\hline 105 & $\bar{K}$ & $03 / 15 / 91$ & $\begin{array}{l}\text { A FIRE OCCURRED IN THE DISASSEMBLY TRANSFER AREA. THE FIRE WAS CAUSED BE } \\
\text { AN ELECTRICAL SHORT ON THE CRANE HAUNCH WHICH BURNED AN ELECTRICAL } \\
\text { CABLE IN TWO. THE FIRE WAS EXTINGUISHED BY AN EMPLOYEE. NO DAMAGE. NO } \\
\text { INJURIES. }\end{array}$ \\
\hline 105 & $P$ & $04 / 17 / 91$ & $\begin{array}{l}\text { A FIRE OCCURRED IN A PORTABLE KANNE MOTOR IN THE DISASSEMBLY AREA. THE } \\
\text { FIRE WAS STARTED WHEN MOTOR OVERHEATED. THE WAS EXTINGUISHED BY AN } \\
\text { EMPLOYEE. NO INIURIES. DAMAGE; } 5200.00 \text {. }\end{array}$ \\
\hline
\end{tabular}

Page 7

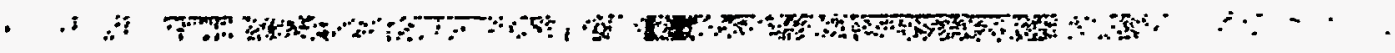




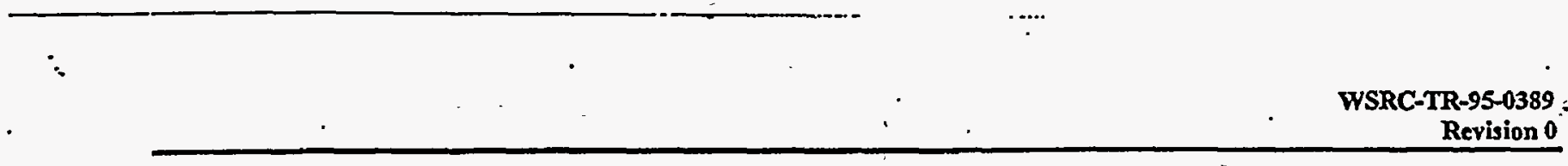

\section{APPENDLX 1: DATA BASE FIRE EVENTS SINCE 1/1/1975}

\begin{tabular}{|c|c|c|c|}
\hline Eacility & & & Description of event \\
\hline 105 & $\mathrm{~K}$ & $06 / 16 / 91$ & $\begin{array}{l}\text { A fire oecurred in a cigarette butt can outside } 105-\mathrm{K} \text { near the purification area. The fire was caused by } \\
\text { discarded smoking material. The fire was extinguished by an employee. No jniuries. No damage. }\end{array}$ \\
\hline 105 & $\mathrm{~K}$ & $01 / 20 / 92$ & $\begin{array}{l}\text { A fire bumed grease on bearing housings of } 910-A \text { and } 910-B \text { fans in the fan room. The fire was caused } \\
\text { when grease overheated. The fire was extinguished by employees. There were no injuries. Cost of } \\
\text { damage was } 52,000.00 \text {. }\end{array}$ \\
\hline 105 & $\bar{k}$ & $01 / 21 / 92$ & $\begin{array}{l}\text { A fire bumed bydraulic hose on a drilling truck at } 105-\mathrm{K} \text { guardhouse. the fire was caused when hose } \\
\text { contacted the truck's exhaust. the fire was extinguished by the Fire Department. there were no injuries. } \\
\text { Damage was } \$ 40.00 \text {. }\end{array}$ \\
\hline 105 & $\mathrm{~K}$ & $12 / 09 / 92$ & $\begin{array}{l}\text { A small transformer for a door indicator shafted out causing smoke and flames. The fire was } \\
\text { extinguished by de-energizing the transformer. Estimated cost is unknown. There were no injuries. }\end{array}$ \\
\hline 105 & $\bar{K}$ & $01 / 22 / 93$ & $\begin{array}{l}\text { A fire oceurred in the distillation area when a portable heater blower malfunctioned causing the heater } \\
\text { to overheat and bum on the.inside of the unit. The fire was extinguished with the use of a } 10-1 \mathrm{~b} A B C \\
\text { portable fire extinguisher. There were no injuries. The estimated damage was } \$ 400.00 \text {. }\end{array}$ \\
\hline 105 & $\bar{K}$ & $05 / 21 / 93$ & $\begin{array}{l}\text { An electrical malfunction occurred in the UPS electrical panel, in the }+15 \text { REMAC Room, during a } \\
\text { power changeover. The fire was extinguished when an employee de-energixed the equipment. There } \\
\text { were no injuries. No damage estimate was reported. }\end{array}$ \\
\hline 105 & $\mathrm{~K}$ & $10 / 05 / 93$ & $\begin{array}{l}\text { On 0-Level an extension cord used for overhead lights malfunctioned causing the cord to bum. The fire } \\
\text { was extinguished when an employee unplugged the cord. Estimated cost for cord replacement ivas } \\
\text { s10.00. there were no injuries. }\end{array}$ \\
\hline 105 & C & $11 / 15 / 93$ & $\begin{array}{l}\text { Behind Disassembly, the heat tracer to the off-loading line shorted out destroying the heat tracer. The } \\
\text { fire was extinguished when the power was disconnected. Estimated darnages were } \$ 85.00 \text {. There were } \\
\text { no injuries. }\end{array}$ \\
\hline 105 & $\bar{R}$ & $03 / 23 / 95$ & $\begin{array}{l}\text { At the construction hut behind } 105-\mathrm{R} \text {, workers using an oxy-acetylene cutting torch for dismantling } \\
\text { basin material equipment, accidentally ignited serap gasket material when sparks from the torch fell into } \\
\text { the scrap pile. Construction workers extinguished the fire using an ABC extinguigher. }\end{array}$ \\
\hline 105 & $\bar{K}$ & $03 / 15 / 93$ & $\begin{array}{l}\text { A kerosene heater bumed in the Distillation Area when an excessive amount of fuel buildup in the unit } \\
\text { ignited causing a fireball. The fire was extinguished using one (1) ten-puond and one (1) fire-pound } \\
\text { ABC fire extinguishers. There were no injuries. No damage estimate was reported. }\end{array}$ \\
\hline 105 & $P$ & $07 / 31 / 93$ & $\begin{array}{l}\text { In Building } 105-P \text { disassembly, a large floor fan sustained damages when the power cord shorted out. } \\
\text { The power cord was wom and brittle on each end. There were no injuries. Damages were estimated at } \\
\text { s15.00. }\end{array}$ \\
\hline
\end{tabular}

\section{Page 8}

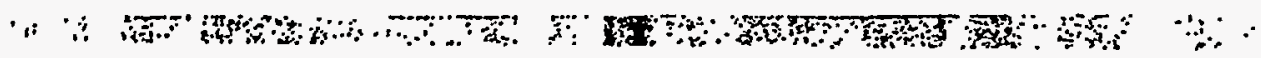




\section{APPENDIX 1: DATA BASE FIRE EVENTS SINCE 1/1/1975}

\begin{tabular}{|c|c|c|c|}
\hline 108 & $\mathrm{~K}$ & $7 / 13 / 87$ & $\begin{array}{l}\text { A FIRE OCCURRED IN 108-IK WHEN THE FEED FOR THE \#I COMPRESSOR SHORTED AND } \\
\text { IGNITED. THE FIRE WAS EXTINGUISHED BY AN EMPLOYEE. DAMAGE UNKNOWN AT } \\
\text { THIS TIME. }\end{array}$ \\
\hline 108 & $P$ & $5 / 9 / 87$ & $\begin{array}{l}\text { A FIRE OCCURRED IN BUILDING 108-1P. A WIRE SHORTED AND IGNITED IN AN AC } \\
\text { GENERATOR THE FIRE WAS EXTINGUISHED BY AN EMPLOYEE. DAMAGE UNKNOWN } \\
\text { AT THIS TIME. }\end{array}$ \\
\hline 108 & $\mathrm{~K}$ & $10 / 5 / 84$ & $\begin{array}{l}\text { A FIRE OCCURRED IN BUILDING 108-1K. A CONTROL TRANSFORMER OVERHEATED } \\
\text { AND IGNIIED, BURNING WIRING AND THE TRANSFORMER. THE FIRE WAS } \\
\text { EXTINGUISHED BY AN EMPLOYEE. DAMAGE WAS ONLY TO THE CONTROL } \\
\text { TRANSFORMER AND WIRING. }\end{array}$ \\
\hline 108 & $\bar{K}$ & $07 / 09 / 90$ & $\begin{array}{l}\text { A FIRE OCCURRED IN BUILDING 108-1K CONTROL ROOM. THE FIRE WAS CAUSED BY } \\
\text { AN ELECTRICAL SHORT IN A CONTROL SWTTCH. THE FIRE WAS EXINGUISHED WHEN } \\
\text { SWITCH WAS DE-ENERGIZED. }\end{array}$ \\
\hline 108 & L & $10 / 10 / 90$ & $\begin{array}{l}\text { A FIRE OCCURRED IN A TRASH CAN ON THE ROOF OF 108-1L. CAUSE OF THE FIRE WAS } \\
\text { A DISCARDED CIGARETIE BUTT. IHE FIRE WAS EXTINGUISHED BY AN EMPLOYEE. }\end{array}$ \\
\hline 108 & L & $11 / 27 / 90$ & $\begin{array}{l}\text { A FIRE OCCURRED IN BUILDING 108-IL COMPRESSOR NO. I STARTER CABINET. THE } \\
\text { FIRE WAS CAUSED BY A SHORT CREATED WHEN THE STARTER CIRCUIT DID NOT DE- } \\
\text { ENERGIZE WHEN COMPRESSOR STARTED. FHE FIRE WAS EXTINGUISHED BY AN } \\
\text { EMPLOYEE. }\end{array}$ \\
\hline 108 & $P$ & $3 / 18 / 82$ & $\begin{array}{l}\text { A FIRE BURNED THE INSULATION ON A NEW ELECTRIC AIR DRYER HEATER IN } 108-2 P \text {. } \\
\text { THE FIRE WAS EXTINGUISHED BY AN EMPLOYEE. DAMAGE WAS LIMITED TO THE } \\
\text { INSULATION. NO DAMAGE ESTIMATE IS AVAILABLE AT THIS TIME. }\end{array}$ \\
\hline 108 & $\mathrm{~K}$ & $2 / 22 / 79$ & $\begin{array}{l}\text { A SMALL FIRE OCCURRED IN THE BUILDING I08-2K EMERGENCY DIESEL ROOM. AN } \\
\text { ELECTRIC MOTOR FOR \#3 AIR COMPRESSOR SHORTED OUT WHEN ENERGIZED } \\
\text { CAUSING THE INSULATION TO BURN. THE FIRE WAS EXTINGUISHED BY THE POWER } \\
\text { OPERATOR USING A CO2 EXTINGUISHER. }\end{array}$ \\
\hline 108 & $L$ & $11 / 28 / 84$ & $\begin{array}{l}\text { A FIRE OCCURRED IN BUILDING } 108 \text {-4L. A TRANSFORMER OVERHEATED AND IGNITED. } \\
\text { THE FIRE WAS EXTINGUISHED BY AN EMPLOYEE. DAMAGE UNKNOWN AT THIS TIME. }\end{array}$ \\
\hline 221 & F & $7 / 13 / 88$ & $\begin{array}{l}\text { A FIRE OCCURRED IN BUILDING } 221-F \text { A-LINE. THE FIRE CHARRED SCAFFOLD BOARDS. } \\
\text { THE BOARDS WERE AGAINST A DENITRATOR. FLUE HEAT FROM THE FLUE CAUSED } \\
\text { THE BOARDS TO CHAR. THE FIRE WAS EXTINGUISHED BY AN EMPLOYEE }\end{array}$ \\
\hline
\end{tabular}

Page 9

: 


\section{APPENDIX 1: DATA BASE FIRE EVENTS SINCE 1/1/1975}

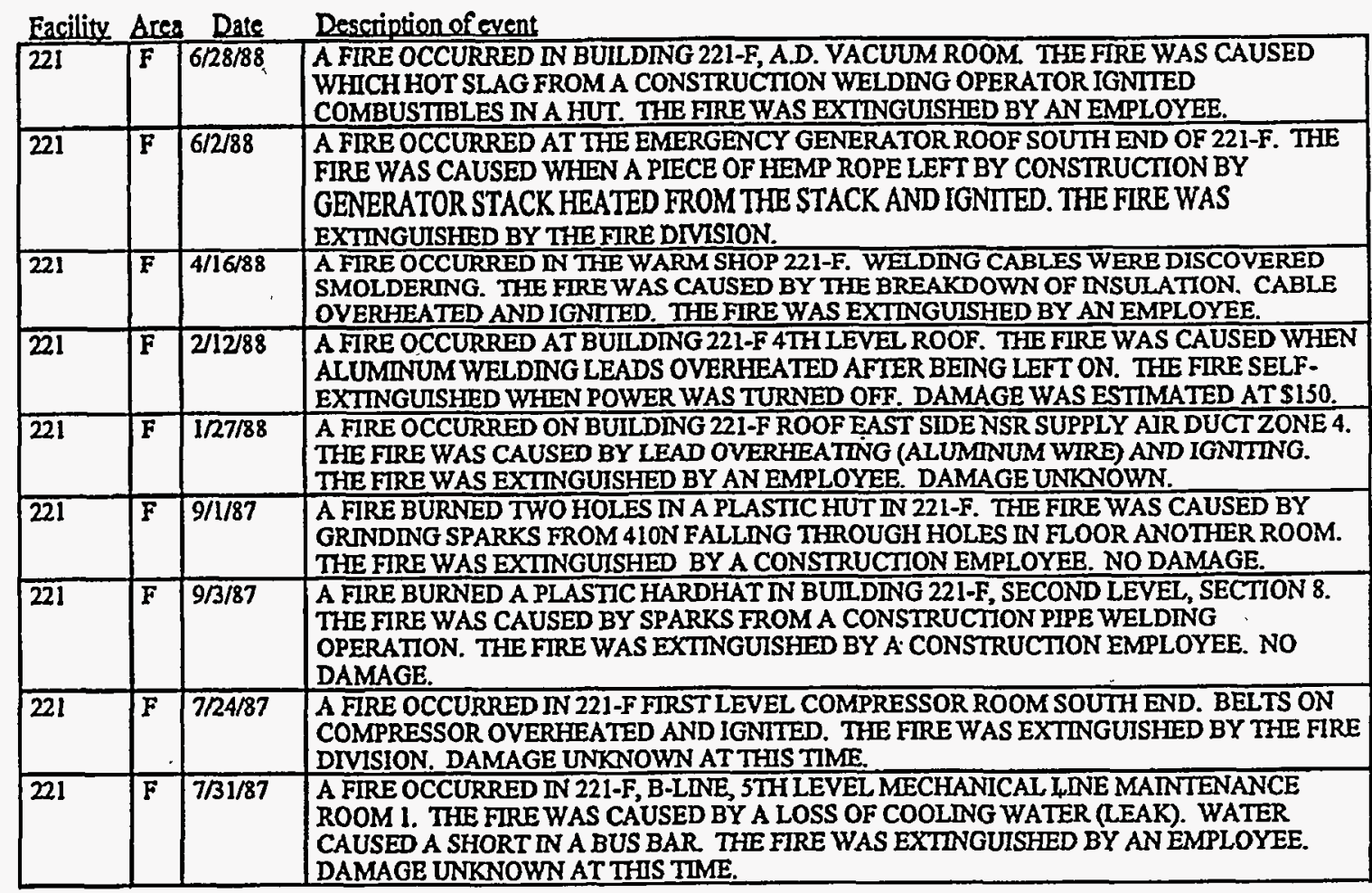

Page 10

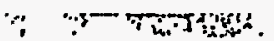

-

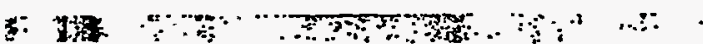


WSRC-TR-95-0389. Revision 0

\section{APPENDIX 1: DATA BASE FIRE EVENTS SINCE 1/1/1975}

\begin{tabular}{|c|c|c|c|}
\hline & & & \\
\hline 221 & $\mathbf{F}$ & $5 / 8 / 87$ & $\begin{array}{l}\text { A FIRE OCCURRED IN BUILDING 221-F B LINE COLUMN FEED HEAD TANK ROOM. THE } \\
\text { FIRE OCCURRED WHEN A CONSTRUCTION EMPLOYEE WAS CHANGING LIGHT BULBS } \\
\text { AND THE LIGHTNG ELEMENT IN A BROKEN BULB ARCHED AGAINST SOME TAPE AND } \\
\text { IGNITED. THE FIRE WAS EXTINGUISHED BY AN EMPLOYEE WITH NO DAMAGE. }\end{array}$ \\
\hline $22 I$ & $\mathrm{H}$ & $6 / 16 / 86$ & $\begin{array}{l}\text { A FIRE OCCURRED IN BUILDING } 221-H_{1}, 6 \text { TH LEVEL COLD FEED PREP, WHEN } \\
\text { PRECIPITATOR NO.2 OVERHRATED AND INSULATION BEGAN TO BURN. THE FIRE WAS } \\
\text { EXTINGUISHED BY AN EMPLOYEE. }\end{array}$ \\
\hline 221 & $\mathbf{F}$ & $5 / 8 / 86$ & $\begin{array}{l}\text { A FIRE OCCURRED IN A B-25 WASTE BOX AT 221-F. THE FIRE WAS CAUSED BY A } \\
\text { CHEMICAL REACTION AND WAS EXIINGUISHED BY THE FIRE DIVISION. NO DAMAGE. }\end{array}$ \\
\hline 221 & $F$ & $4 / 1 / 86$ & $\begin{array}{l}\text { A FIRE OCCURRED IN BUILDING 221-F B-LINE, FIFTH LEVEL. THE FIRE WAS CAUSED BY } \\
\text { A SHORT N WELDING CABLES. THE FIRE WAS EXIINGUISHED BY AN EMPLOYEE. } \\
\text { DAMAGE WAS TO THE WELDING CABLE ONLY. }\end{array}$ \\
\hline 221 & $F$ & $12 / 14 / 85$ & $\begin{array}{l}\text { A FIRE OCCURRED IN BUIIDING 221-F. A PAIR OF COVERALLS WAS DISCOVERED } \\
\text { SMOLDERING IN A WASTE BOX. THE FIRE WAS CAUSED BY DISCARDED EPOXY } \\
\text { ADHESIVE USED BY CONSTRUCIION. THE FIRE WAS EXIINGUISHED BY AN EMPLOYEE. } \\
\text { NO DAMAGE. }\end{array}$ \\
\hline 221 & $F$ & $7 / 28 / 85$ & $\begin{array}{l}\text { A FIRE OCCURRED IN 221-F A-LINE. OIL IN THE DENITRATOR OVERHEATED AND } \\
\text { IGNITED. THE FIRE WAS EXIINGUISHED BY THEE FLRE DIVISION. NO DAMAGE. }\end{array}$ \\
\hline 221 & $F$ & $1 / 27 / 85$ & $\begin{array}{l}\text { A FIRE OCCURRED IN B-LINE, } 221 \text {-F WHEN A HYPOLON GLOVE WAS IGNITED BY A } \\
\text { IIGHT BULB. THE GLOVE WAS TOO CLOSE TO THE BULB. THE FIRE WAS } \\
\text { EXIN GUISHED BY AN EMPLOYEE. NO DAMAGE. }\end{array}$ \\
\hline 221 & $F$ & $11 / 3 / 84$ & $\begin{array}{l}\text { A FIRE OCCURRED IN } 221 \text {-F JB IINE. PAINT ON THE TOP OF A CABINET IGNITED AND } \\
\text { BURNED. THE FIRE WAS CAUSED BY SPARKS FROM A CONSTRUCTION WELDING } \\
\text { OPERATION. THE FIRE WAS EXTINGUISHIED BY AN EMPLOYEE. NO MONETARY } \\
\text { DAMAGE WAS SUSTAINED. }\end{array}$ \\
\hline 221 & $F$ & $11 / 11 / 83$ & $\begin{array}{l}\text { A FIRE OCCURRED IN BUILDING 221-F AIR COMPRESSOR ROOM WHEN A BEARING } \\
\text { OVERHEATED CAUSING A MOTOR TO BURN. THE FIRE WAS EXTINGUISHED BY AN } \\
\text { EMPLOYEE AND DAMAGE WAS CONFINED TO THE MOTOR. LOSS IS LIMITED TO } \\
\text { REPLACEMENT OF THE MOTOR. }\end{array}$ \\
\hline 221 & $\mathrm{H}$ & $2 / 3 / 83$ & $\begin{array}{l}\text { A LIGHT BALLAST SHORTED AND FLAMED UP IN BUILDING 221-H, 4TH LEVEL. THE } \\
\text { FIRE WAS CAUSED BY AN ELECTRICAL SHORT AND WAS EXTINGUISHED BY CUTTING } \\
\text { THE POWER. DAMAGE WAS LIMIED TO THE LIGHT FIXTURE AND ESTIMATED AT } \\
\text { APPROXIMATELY S100. }\end{array}$ \\
\hline
\end{tabular}

Page 11 


\section{APPENDIX 1: DATA BASE FIRE EVENTS SINCE 1/1/1975}

\begin{tabular}{|c|c|c|c|}
\hline 221 & $\mathrm{H}$ & $6 / 24 / 82$ & $\begin{array}{l}\text { A FIRE OCCURRED IN THE WARM SAMPLE AISLE OF 221-H. THE FIRE BURNED A WASTE } \\
\text { BOX AND A TIRE ON AN OXY-ACETYLENE CART. THE FIRE APPARENTLY STARTED } \\
\text { FROM A PIPE BURNING OPERATION ON THE DAY SHFT AND WAS NOT DISCOVERED } \\
\text { UNTIL 5:00 PM ON THE NEXT SHIIFT. THERE WAS NO CONTAMINATION RELEASE. } \\
\text { DAMAGE IS ESTIMATED ATLESS THAN } \$ 200.00 \text {. }\end{array}$ \\
\hline 221 & $\mathrm{H}$ & $3 / 2 / 82$ & $\begin{array}{l}\text { A FIRE OCCURRED IN THE 221-H HOT SAMPLE AISLE WHEN A PLASTIC WRAPPED } \\
\text { WASTE BOXIGNITED. THE FIRE WAS EXINGUISHED BY EMPLOYEES AND DAMAGE } \\
\text { WAS LIMITED TO THE PLASTIC. IT IS BELIEVED THE FIRE WAS STARTED WHEN ACID- } \\
\text { SOAKED WASTE SELF.IGNITED. NO DAMAGE WAS SUSTAINED. }\end{array}$ \\
\hline 221 & $\mathrm{H}$ & $1 / 30 / 80$ & $\begin{array}{l}\text { A NEW PLASTIC BAGGED HEPA FILTER WAS PLACED IN } 221 \text {-H LINE RECOVERY } \\
\text { CABINET. INADVERTENTLY, THE FII TER WAS PLACED ON A HOT DISSOLVER, WHICH } \\
\text { IS BELIEVED TO HAVE IGNITED THE PLASTIC BAG. AN AUTOMATIC HAION SYSTEM } \\
\text { EVENTUALY EXTINGUISHED THE FIRE. TWO CABINET WINDOWS WERE CRACKED. } \\
\text { NO CONTAMINATION RELEASE TO ATMOSPHERE, VERY LITTLE N ROOM. }\end{array}$ \\
\hline 221 & $\mathbf{H}$ & $8 / 14 / 79$ & $\begin{array}{l}\text { A FIRE BURNED A SOLENOID ON A FLOW CONTROL VALVE IN SECTION } 15,221-\mathrm{H} \\
\text { SECOND LEYEL. THE FIRE WAS EXIINGUISHED BY AN EMPLOYEE. CAUSE IS } \\
\text { UNKNOWN. }\end{array}$ \\
\hline 221 & F & $10 / 9 / 78$ & $\begin{array}{l}\text { A FIRE OCCURRED IN BUILDING 221-F A-LINE WHEN THE SHAFT SEAL ON THE PLOW } \\
\text { BLADE OF DENITRATOR C-3-1 FAILED, DROPPING OIL INTO THE HOT POT. THE } \\
\text { RESULTING FLASH FIRE WAS EXINGUISHED BY AN EMPLOYEE. }\end{array}$ \\
\hline 221 & $\bar{F}$ & $10 / 16 / 78$ & $\begin{array}{l}\text { A FIRE OCCURRED IN 221-F A-LINE WHEN ATOMIC WIPES BEING USED TO CLEAN UP A } \\
\text { LIQUID SPILL ON TOP OF DENITRATOR C-3-2 IGNITED AFIER THEY WERE THROWN } \\
\text { INTOA WASTE RECEPTACLE. THE FIRE WAS EXINNGUSHIED BY AN EMPLOYEE. }\end{array}$ \\
\hline 221 & F & $8 / 31 / 78$ & $\begin{array}{l}\text { AN INDUSTRIAL FIRE OCCURRED IN } 221 \text {-F 6TH LEVEL. DISSOLVER OPERATING ROOM } \\
\text { WELDING WAS BENNG DONE INSDE A PLASTIC CONTAMINATION CONTAINMENT HUT. } \\
\text { HEAT CAUSED TAPE USED TO PREPARE HUT TO IGNITE. }\end{array}$ \\
\hline 221 & F & $4 / 2275$ & $\begin{array}{l}\text { B-LINE, } 221-F \text {. WELDING SPARKS DROPPED ONA FOLDED WASTE BOX. FIRE WAS } \\
\text { EXIINGUISHED WITHA CO2 FIRE EXIINGUISHER }\end{array}$ \\
\hline 221 & S & $09 / 14 / 90$ & $\begin{array}{l}\text { A FIRE WAS DISCOVERED IN A BUTT CAN IN BUILDING 221-S, STAIRWELL, 6, LEVEL 1. } \\
\text { THE.FIRE WAS SUSPECTED TO BE CAUSED BY DISCARDED SMOKNG MATERIAL. THE } \\
\text { FIRE WAS EXINGUISHED BY AN EMPLOYEE. }\end{array}$ \\
\hline 221 & $\mathrm{H}$ & $11 / 29 / 90$ & $\begin{array}{l}\text { A FIRE OCCURRED IN A COPIER IN BUILDING 221-H. THE FIRE WAS CAUSED BY A JAM } \\
\text { IN THE MACHINE. THE FIRE BURNED OUT. }\end{array}$ \\
\hline
\end{tabular}

Page 12 
WSRC-TR-95-0389: Revision 0

\section{APPENDIX 1: DATA BASE FIRE EVENTS SINCE 1/1/1975}

\begin{tabular}{|c|c|c|c|}
\hline Eacility & & & Description of event \\
\hline 221 & $\mathbf{F}$ & $11 / 17 / 91$ & $\begin{array}{l}\text { A fire occurred in FB-Line } 5 \text { th level mechanical line control room. The fire was caused by possible } \\
\text { overheating in the compressor compartment of the } \# 2 \mathrm{~A} / \mathrm{C} \text { unit. The fire was extinguished by an } \\
\text { employee. No injuries. Damage; } \$ 912.00 \text {. }\end{array}$ \\
\hline 22.1 & $F$ & $08 / 19 / 91$ & $\begin{array}{l}\text { A scaffolding was located above the } 221-F \text { emergency diesel generator exhaust system. The diesel was } \\
\text { in operation, which caused the scaffolding to heat up and smolder. The heat caused scorching and } \\
\text { blackening to the scaffolding boards. No injuries and no damage. }\end{array}$ \\
\hline 221 & $\mathrm{H}$ & $06 / 10 / 92$ & $\begin{array}{l}\text { In the Hot Crane Cab, a } 13 \text {-pound Halon } 1211 \text { extinguisher was discharged to extinguish a short in the } \\
\text { electrical wiring. Damage was minimal. There were no injuries. }\end{array}$ \\
\hline 221 & $F B$ & $08 / 05 / 92$ & $\begin{array}{l}42 \text { pounds of Halon was discharged manually when sparks from a maintenance mechanic welding torch } \\
\text { ignited Class A materials below the scaffolding on which the work was being performed. There were } \\
\text { no injuries. Damage was estimated to be } \$ 123.90 \text {. }\end{array}$ \\
\hline 221 & $F$ & $03 / 02 / 93$ & $\begin{array}{l}\text { A fire oceured on the 3rd level, Section 8, when sparks of hot metal particles falling through a } \\
\text { ventilation duct opening from the } 4 \text { th level during grinding activities caused dust on the top of a ceiling } \\
\text { duct to smoke and smolder. Operations personnel located and removed the hot particles and placed } \\
\text { them into a bucket of water to be extinguished. There ivere no injuries. No damage estimate was } \\
\text { reported. }\end{array}$ \\
\hline 221 & $\mathrm{H}$ & $04 / 12 / 93$ & $\begin{array}{l}\text { On the.2nd level, Section } 10,2 \text { fire oceurred when an electrical short in the wiring supplying the } 10.3 \mathrm{C} \\
\text { Melotron pressure switch malfunctioned, causing the Melotron switch to bum. There were no } \\
\text { injuries. Estimated damage was } \$ 584.00 \text {. }\end{array}$ \\
\hline 221 & $S$ & $10 / 11 / 93$ & $\begin{array}{l}\text { While workers were welding on the roof of } 221-S \text {, the fire retardant cloth cover slipped and exposed a } \\
\text { cloth cover to welding slag, which started to smolder. The fire was extinguished using a } 10 \mathrm{lb} \text {. ABC } \\
\text { extinguisher. There was no damage and no injuries. }\end{array}$ \\
\hline 221 & $\mathrm{H}$ & $02 / 15 / 94$ & $\begin{array}{l}\text { In MCC \#4, lst level, construction was welding a support for new conduit in the ceiling when a spark } \\
\text { fell on a mop head causing the mop heat to ignite. Construetion worker extinguished the fire using an } \\
\text { ABC fire extinguisher. Estimated damage was S10.00. There were no injuries. }\end{array}$ \\
\hline 221 & $S$ & $04 / 05 / 94$ & $\begin{array}{l}\text { On the 3rd lovel east, fire prolection wejders were welding pipe brackets to the ceiling when sparks } \\
\text { from the welding dropped into debris on top of the air duct, causing it to ignite. The fire was } \\
\text { extinguished by a fire watch using an ABC extinguisher. Estimated damage was } \$ 15.00 \text {. There were } \\
\text { no injuries. }\end{array}$ \\
\hline 221 & $\begin{array}{l}\mathbf{H} \\
\mathbf{B}\end{array}$ & $04 / 15 / 94$ & $\begin{array}{l}\text { In glove box } \$ 9 \text {, a lab technician discovered flames and smoke coming from a cleaning cloth that was } \\
\text { lying on top of a multiple-outlet receptacle strip in the glove box. Estimated damages were } \$ 25.00 \text {. } \\
\text { There were no injuries. }\end{array}$ \\
\hline
\end{tabular}

Page 13

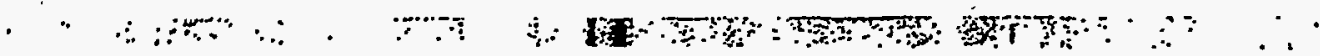




\section{APPENDIX 1: DATA BASE FIRE EVENTS SINCE 1/1/1975}

\begin{tabular}{|c|c|c|c|}
\hline Eacility & Are & a Date & Description of event \\
\hline 221 & $F$ & $5 / 12 / 94$ & $\begin{array}{l}\text { A small deep seated fire involving Class A materials (rags, wooden spool, and a nylon rope) occurred in } \\
\text { the Warm Canyon shop. The fire was from an unknown origin but was believed to have started from a } \\
\text { welding job that was performed earlier that day. Three } 10 \text {-pound ABC fire extinguishers were used } \\
\text { during the extinguishment. Estimated damages were } \$ 40.00 \text {. There were no injuries. }\end{array}$ \\
\hline 221 & $F$ & $05 / 03 / 95$ & $\begin{array}{l}\text { In the lst level, section 5, during a transformer replacement, a transformer shorted out and began to } \\
\text { smoke. The power was de-energized and the fire was extinguished. Estimated damage received was } \\
\$ 600.00 \text {. There were no injuries. }\end{array}$ \\
\hline 221 & $F$ & $7 / 21 / 80$ & $\begin{array}{l}\text { A FIRE OCCURRED IN THE JB-LINE, MECHANICAL IINE PRESSURE CHAMBER MAKE UP } \\
\text { STATION GLOVE BOX. THE FIRE STARTED WHEN A VACUUM CLEANER SHORTED. IT } \\
\text { WAS EXTINGUISHED BY AN EMPLOYEE PUNCTURING A GLOVE AND USING AN } \\
\text { EXTINGUISHER DAMAGES WERE CONFINEO TO THE VACUUM CLEANER. }\end{array}$ \\
\hline 221 & $\bar{F}$ & $06 / 16 / 91$ & $\begin{array}{l}\text { A fire occurred in the } A \text {-Line at column F-8. The fire was caused when acid fumes leaking from a line } \\
\text { ignited insulation around pipe. The fire was extinguished by an employee. No injuries. Damage; } \\
\text { s10,000.00. }\end{array}$ \\
\hline 221 & $H$ & $12 / 15 / 93$ & $\begin{array}{l}\text { A welding cable used by construction workers shorted out and melted the insulation from the connector } \\
\text { end, causing a fire. The fire was extingu9ished using a fire extinguisher. Estimated damage was } \\
\text { \$75.00. There were no injuries. }\end{array}$ \\
\hline $221-1$ & $F$ & $1 / 20 / 89$ & $\begin{array}{l}\text { A FIRE BURNED INSULATION ON DENITRATOR FURNACE GAS PIPE. THE INSULATION } \\
\text { OVERHEATED AND IGNITED. THE FIRE WAS EXTINGUISHED BY AN EMPLOYEE. }\end{array}$ \\
\hline $221-1$ & $F$ & $12 / 03 / 93$ & $\begin{array}{l}\text { In the lst level MCC, the transformer control circuitry shorted out when the powver was restored to the } \\
221-1 \mathrm{~F} \text { Building. The fire self-extinguished when the power was de-energized to the transformer. } \\
\text { Estimated damage.was } \$ 100.00 \text {. There were no injuries. }\end{array}$ \\
\hline 221 & $F$ & $06 / 05 / 94$ & $\begin{array}{l}\text { In Section 1, the electrical wiring on a disconnect switch overheated and burned, causing estimated } \\
\text { damages of } \$ 2,600 \text {. the fire was extinguished using a } 10 \mathrm{lb} \text {. ABC fire extinguisher. There vere no } \\
\text { injuries. }\end{array}$ \\
\hline 232 & $\mathrm{H}$ & $12 / 10 / 86$ & $\begin{array}{l}\text { A FIRE OCCURRED IN 232-H, -17 LEVEL IN THE LINE } 1 \text { PROCESS ROOM PY2 HOOD. PIPE } \\
\text { FITTERS WERE REMOVING AN ELL FROM A REFRIGERATION LNEE WHEN THE ELL } \\
\text { BROKE AND THE COMPRESSOR OIL RELEASED IGNTED. NO DAMAGE. }\end{array}$ \\
\hline 232 & $H$ & $11 / 1 / 83$ & $\begin{array}{l}\text { THREE V BELTS IGNITED AND BURNED ON A PUMP IN 232-H. THE FIRE WAS } \\
\text { EXTINGUISHED BY AN EMPLOYEE AND DAMAGE WAS LIMIIED TO THREE V BELTS. } \\
\text { MONETARY LOSS WAS S15. }\end{array}$ \\
\hline
\end{tabular}

Page 14

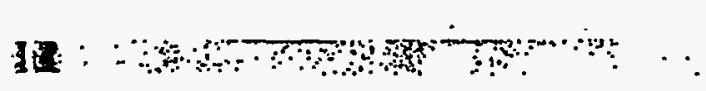




\section{APPENDIX 1: DATA BASE FIRE EVENTS SINCE 1/1/1975}

Facility Area Date Description of event

\begin{tabular}{|c|c|c|c|}
\hline 232 & $\mathrm{H}$ & $2 / 4 / 76$ & $\begin{array}{l}\text { A FIRE OCCURRED IN 232-H BASEMENT, CLEAN MECHANICAL ROOM. MAINTENANCE } \\
\text { WAS BURNING BOLTS OFF FLANGES OF COOLING WATER INLET LNNES PREPARATORY } \\
\text { TO REPAIR OF COILS DAMA GED DURING FREEZING WEATHER CORK INSULATION } \\
\text { BEGAN SMOLDERINO DUE TO HEATIAIR FLOW ACROSS INSULATION }\end{array}$ \\
\hline 232 & H & $05 / 04 / 90$ & $\begin{array}{l}\text { A FIRE OCCURRED IN THE DIESEI GENERATOR ROOM } 1 \text { LEVEL } 11 \text {, BUIIDING 232-H. } \\
\text { INSULATION PAPER ON DIESEL GENERATOR EXHAUST OVERHEATED AND FLAMED UP. } \\
\text { IHE FIRE WAS EXTINGUISHED BY AN EMPLOYEE. DAMAGE UNKNOWN. }\end{array}$ \\
\hline 234 & $\overline{\mathrm{H}}$ & $1 / 21 / 82$ & $\begin{array}{l}\text { A FIRE OCCURRED IN A POWER SUPPLY TRANSFORMER IN BLDG. 234-H. THE CAUSE OF } \\
\text { THE FIRE IS UNKNOWN. IT WAS EXTINGUISHED BY EMPLOYEES. }\end{array}$ \\
\hline 234 & $\overline{\mathrm{H}}$ & $06 / 17 / 90$ & $\begin{array}{l}\text { A FIRE OCCURRED IN BUILDNG 234-H THE FIRE WAS CAUSED WHEN COMPRESSOR } \\
\text { BEARINGS FROZE UP AND BURNED DRIVE BELTS AND OIL ABSORBENT PIGS AROUND } \\
\text { COMPRESSOR ALSO BURNED. THE FIRE WAS EXTINGUISHED BY AN EMPLOYEE. }\end{array}$ \\
\hline 234 & $\bar{H}$ & $12 / 11 / 90$ & $\begin{array}{l}\text { A FIRE OCCURRED IN THE ENGINE COMPARTMENT OF A FORKLIFT BEING USED AT THE } \\
\text { 234-H NORTH LOADNG DOCK. THE BATTERY CABLES SHORTED OUT, CAUSING THE } \\
\text { FIRE. THE FIRE WAS EXTINGUISHED BY THE OPERATOR. NO INJURIES. }\end{array}$ \\
\hline 234 & $\mathbf{H}$ & $09 / 05 / 91$ & $\begin{array}{l}\text { At Intermediate Tritium a small gasoline engine ignited and bumed. The cause was a leaking } \\
\text { carburetor. The fire was extinguished by construction personnel using two (2) ten-pound ABC } \\
\text { extinguishers. There were non injuries. The motor was replace with no loss in production. The total } \\
\text { fire damage was } 550.00 \text {. }\end{array}$ \\
\hline 234 & H & $06 / 04 / 93$ & $\begin{array}{l}\text { At } 2 \text { construction shed next to } 234-\mathrm{H} \text {, where a welder was cutting metal, sparks ignited dry grass in the } \\
\text { area. The fire was extinguished using a 10-puond ABC extinguisher and water from a fire apparatus. } \\
\text { There were no injuries.No damage estimate was reported. }\end{array}$ \\
\hline 235 & F & $12 / 17 / 80$ & $\begin{array}{l}\text { A FIRE BURNED A LIGHT BALLAST IN BLDG. } 235 \text {-F. IT WAS EXTINGUISHED BY AN } \\
\text { EMPLOYEE. DAMAGES WERE APPROXIMATELY } \$ 25.00 .\end{array}$ \\
\hline 235 & $F$ & $10 / 5 / 89$ & $\begin{array}{l}\text { A FIRE OCCURRED IN BUILDING 235-F PLUTONIUM EXPERIMENTAL FACILITY. THE FIRE } \\
\text { WAS CAUSED WHEN A VACUUM PUMP MOTOR BURNED OUT. THE FIRE WAS } \\
\text { EXTINGUISHED WHEN THE HALON SYSTEM WAS ACTIVATED. I }\end{array}$ \\
\hline 235 & $\bar{F}$ & $01 / 23 / 90$ & $\begin{array}{l}\text { A FIRE OCCURRED IN A PROPANE TORCH. THE FIRE WAS CAUSED WHEN A LEAK IN } \\
\text { THE BOTILE IGNITED. THE FIRE WAS EXIINGUISHED BY AN EMPLOYEE. }\end{array}$ \\
\hline 247 & $F$ & $1 / 25 / 88$ & $\begin{array}{l}\text { A FIRE OCCURRED IN BUILDNNG 247-F AT WASTE WATER HOLDING TANK \# 2, PH } \\
\text { SAMPLING STATION. THE FIRE WAS CAUSED BY AN ELECTRICAL SHORT IN A HEAT } \\
\text { TRACING WHICH IGNITED INSULATION AND BURNED. THE FIRE WAS EXTINGUISHED } \\
\text { BY AN EMPLOYEE. DAMAGE ESTIMATED AT LESS THAN S100. }\end{array}$ \\
\hline
\end{tabular}

Page 15

: 


\section{APPENDIX 1: DATA BASE FIRE EVENTS SINCE 1/1/1975}

\begin{tabular}{|c|c|c|c|}
\hline Eacility & Are? & Date & Descriotion of event \\
\hline 247 & $F$ & $5 / 24 / 87$ & $\begin{array}{l}\text { A FIRE OCCURRED IN BUILDING 247-F SEMI-FINISHING FURNACE ROOM. THE FIRE WAS } \\
\text { CAUSED BY RODS THAT OVERHEATED, IGNITING TWO BEARING BLOCKS WHICH } \\
\text { IGNITED THE PLEXIGLASS SHIELD. THE FIRE WAS EXINGUISHED BY AN EMPLOYEE. } \\
\text { DAMAGE \$50. }\end{array}$ \\
\hline 247 & $\bar{F}$ & $1 / 25 / 89$ & $\begin{array}{l}\text { A FIRE OCCURRED IN BUILDING 247-F. SOUTH FINISHING ROOM. THE FIRE WAS } \\
\text { CAUSED BY SOLUTON THAT WAS BEING CLEANED FROM EQUIPMENT. THE FIRE WAS } \\
\text { EXTINGUISHED BY AN EMPLOYEE. }\end{array}$ \\
\hline 247 & $F$ & $08 / 13 / 90$ & $\begin{array}{l}\text { A FIRE OCCURRED IN BUILDING 247-F WASTE WATER TREATMENT FACILITY. THE FIRE } \\
\text { WAS CAUSED WHEN A SLICE CONNECTOR ON A HEAT TRACE WIRE BROKE AND } \\
\text { IGNITED INSULATOR THE FIRE WAS EXTINGUUSHED BY AN EMPLOYEE. }\end{array}$ \\
\hline 247 & $F$ & $09 / 26 / 94$ & $\begin{array}{l}\text { Subcontractors on top of the building, used gasoline to exterminate a bed of fire ants while replacing the } \\
\text { roof. When grinding operations began later that day the gasoline ignited but caused no damages. the } \\
\text { fire was extinguished using an } A B C \text { portable fire extinguisher. There were no injuries. }\end{array}$ \\
\hline 313 & $\bar{M}$ & $6 / 9 / 88$ & $\begin{array}{l}\text { A FIRE OCCURRED ON THE ROOF OF BUILDING 313-M THE FIRE OCCURRED WHEN A } \\
\text { SUBCONTRACT EMPLOYEE WAS USING A HEAT GUN TO DRY WOOD. A PIECE OF } 2 \text { X } 4 \\
\text { IGNITED. THE FIRE WAS EXTINGUISHED BY AN EMPLOYEE. }\end{array}$ \\
\hline 313 & $\bar{M}$ & $2 / 4 / 88$ & $\begin{array}{l}\text { A FIRE OCCURRED IN BUILDING 313-MHDSB PIT. THE FIRE WAS CAUSED WHEN AN } \\
\text { ELECTRICAL CABLE ARCED AND BEGUN TOMELT. MOLTEN COPPER FELL ON } \\
\text { CARDBOARD AND IGNIIED. THE FIRE WAS EXINGUISHED BY AN EMPLOYEE. } \\
\text { DAMAGE UNKNOWN. }\end{array}$ \\
\hline 313 & $\bar{M}$ & $5 / 7 / 87$ & $\begin{array}{l}\text { A FIRE OCCURRED IN BUILDING 313-M CAP CAN ROOM. GREASE WAS IGNITED IN A } \\
\text { DEGREASER TANK FROM A WELDING OPERATION. THE FIRE WAS EXIINGUISHED BY } \\
\text { AN EMPLOYEE. NO DAMAGE. }\end{array}$ \\
\hline 313 & $\mathbf{M}$ & $1 / 21 / 87$ & $\begin{array}{l}\text { A FIRE OCCURRED IN THE HDS PRESS EXIAAUST HOOD IN 313-M AS THE RESULT OF A } \\
\text { CONSTRUCTION WELDING OPERATION. THE FIRE WAS EXIINGUISHED BY AN } \\
\text { EMPLOYEE. NO DAMAGE. }\end{array}$ \\
\hline 313 & $M$ & $11 / 3 / 86$ & $\begin{array}{l}\text { A FIRE OCCURRED IN 313-M AUTOCLAVE PIT. FIVE GALLONS OF PAINT BURNED WHEN } \\
\text { CONSTRUCTION WELDING SET OFF FUMES IN A PAINT CAN. THE FIRE WAS } \\
\text { EXINGUISHED BY AN EMPLOYEE, AND NO DAMAGE WAS SUSTAINED. }\end{array}$ \\
\hline 313 & $\mathbf{M}$ & $11 / 8 / 86$ & $\begin{array}{l}\text { A FIRE OCCURRED IN BUILDING 313-M BASEMENT. THE FIRE WAS CAUSED BY A } \\
\text { CONSTRUCTION WELDING OPERATION. OIL AND GREASE ON A CONDENSATE TANK } \\
\text { IGNIIED AND BURNED. THE FIRE WAS EXINGUISHED BY CONSTRUCTION. NO } \\
\text { DAMAGE. }\end{array}$ \\
\hline
\end{tabular}




\section{APPENDIX 1: DATA BASE FIRE EVENTS SINCE 1/1/1975}

\begin{tabular}{|c|c|c|c|}
\hline Facility & & Date & Description of event \\
\hline 313 & $M$ & $9 / 17 / 85$ & $\begin{array}{l}\text { A FIRE OCCURRED IN BUILDING 313-M AT THE HOT DIE SIZE PRESS. A HOT SLUG FELL } \\
\text { FROM THE MACHINE THROUGH GRATING AND IGNITED OILY RESIDUE. THE FIRE WAS } \\
\text { EXIINGUISHED BY AN EMPLOYEE. NO DAMAGE OR LOSS TO PRODUCTION. }\end{array}$ \\
\hline 313 & $M$ & $9 / 25 / 85$ & $\begin{array}{l}\text { A FIRE OCCURRED IN } 313-M \text { WHEN THE TURRET ARM AT THE PRESS DROPPED A SLUG } \\
\text { IN THE PIT UNDER TIE TURRET. THE FIRE WAS EXTINGUISHED BY AN EMPLOYEE. NO } \\
\text { DAMAGE. }\end{array}$ \\
\hline 313 & $\mathbf{M}$ & $1 / 31 / 85$ & $\begin{array}{l}\text { A FIRE OCCURRED IN } 313-M \text {. THE FIRE WAS CAUSED BY AN ELECTRICAL SHORT ON A } \\
\text { SOLENOID VALVE. THE FIRE WAS EXTINGUISHED BY AN EMPLOYEE. NO DAMAGE. }\end{array}$ \\
\hline 313 & $\mathbf{M}$ & $1 / 31 / 85$ & $\begin{array}{l}\text { A FIRE OCCURRED IN } 313-M \text { PRESS AREA. THE FIRE WAS CAUSED BY HOT METAL } \\
\text { FALLING ON CARDBOARD WHICH.IGNITED. THE FIRE WAS EXINIGUISHED BY AN } \\
\text { EMPLOYEE NO DAMAGE WAS INCURRED. }\end{array}$ \\
\hline 313 & $\mathbf{M}$ & $10 / 16 / 84$ & $\begin{array}{l}\text { AN ELECTRICAL FIRE OCCURRED IN BUILDING 313-M. AN ARCO WELDERTRIMMER } \\
\text { CAUGHT FIRE WHEN A ROLLER BOUND UP ON HOUSING. THE FIRE WAS } \\
\text { EXTINGUISHED BY AN EMPLOYEE. DAMAGES HAVE NOT BEEN DETERMINED. }\end{array}$ \\
\hline 313 & $\bar{M}$ & $1 / 4 / 84$ & $\begin{array}{l}\text { A FIRE OCCURRED IN 313-M. THE ENDBONDER MOTOR OVERHEATED AND IGNITED } \\
\text { WIRNG OF MOTOR AND GREASE. THE FIRE WAS EXTIGUISHED BY AN EMPLOYEE. } \\
\text { DAMAGE WAS TO THE MOTOR AND WIRING. LOSS UNKNOWN AT THS TIME. }\end{array}$ \\
\hline 313 & $\bar{M}$ & $12 / 12 / 83$ & $\begin{array}{l}\text { A FIRE OCCURRED IN 313-M DISTILL DEGREASER TANK WHEN LIQUID VAPOR FROM } \\
\text { TRICHLOROETHANE IGNITED. CAUSE OF FIRE IS UNKNOWN. FIRE WAS } \\
\text { EXIINGUISHED BY AN EMPLOYEE. NO MONETARY LOSS SUSTAINED. }\end{array}$ \\
\hline 313 & $M$ & $11 / 12 / 83$ & $\begin{array}{l}\text { A FIRE OCCURRED IN BUILDING 313-M AT THE END BONDER WHEN A HYDRAULIC HOSE } \\
\text { BURNT AND SPRAYED OIL ON A HEATING COIL. THE FIRE WAS EXTINGUISHED BY AN } \\
\text { EMPLOYEE AND DAMAGE WAS LIMITED TO THE HYDRAULIC HOSE. }\end{array}$ \\
\hline 313 & $\vec{M}$ & $10 / 22 / 82$ & $\begin{array}{l}\text { A CUT-OFF SAW CUT INTO A SLUG CAUSING SPARKS WHICH IGNTTED OIL RESIDUE ON } \\
\text { THE SAW BLADE IN } 313-M \text {. THE FIRE WAS EXTINGUISHED BY AN EMPLOYEE. NO } \\
\text { CONTAMINATION OR PROPERTY LOSS RESULTED. }\end{array}$ \\
\hline 313 & $\bar{M}$ & $8 / 31 / 82$ & $\begin{array}{l}\text { THE REMANS OF A URANIUM SLUG BURNED IN 313-M AFTER BEING DISCHARGED } \\
\text { FROM AN AUTOCLAVE. THE SLUG WAS COVERED WITH G-1 POWDER TO STOP THE } \\
\text { OXIDATION PROCESS. NO CONTAMINATION OR PROPERTY LOSS RESULTED FROM THE } \\
\text { INCIDENT. }\end{array}$ \\
\hline 313 & $M$ & $7 / 29 / 82$ & $\begin{array}{l}\text { A FIRE OCCURRED IN THE 313-M HOT DIE SIZR PIT WHEN A SLUG DROPPED IN THE PIT } \\
\text { IGNITING OIL ON THE FLOOR IT WAS EXIINGUISHED BY AN EMPLOYEE. THERE WERE } \\
\text { NO DAMAGES. }\end{array}$ \\
\hline
\end{tabular}

Page 17

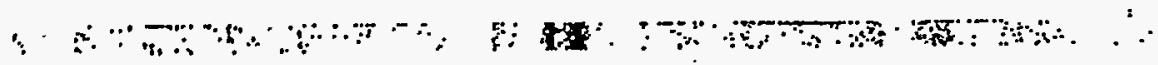




\section{APPENDIX 1: DATA BASE FIRE EVENTS SINCE 1/1/1975}

\begin{tabular}{|c|c|c|c|}
\hline Eacility & Ares & Date & Description of event \\
\hline 313 & $\mathbf{M}$ & $1 / 21 / 82$ & $\begin{array}{l}\text { A FIRE OCCURRED IN 313-M WHEN A CUT-OFF SAW HIT A URANIUM CORE. THE SPARKS } \\
\text { FROM THS ACIION IGNITED THE OLLY FILM ON THE SAW GUARD. A MALFUNCIION OF } \\
\text { THE CORE POSITIONER PROBE PLACED THE CORE IN THE PATH OF THE SAW BLADE. } \\
\text { THE FIRE WAS EXIINGUISHED BY AN EMPLOYEE. NO DAMAGES WERE INCURRED. }\end{array}$ \\
\hline 313 & $\bar{M}$ & $4 / 3 / 81$ & $\begin{array}{l}\text { A FIRE OCCURRED IN THE HOT DIE SIZE PIT IN 313-M. THE FIRE STARTED WHEN HOT } \\
\text { METAL DROPPED ON LUBRICATING OIL IN THE PIT. IT WAS EXIINGUISHED BY AN } \\
\text { EMPLOYEE. NO DAMAGE WAS SUSTAINED. }\end{array}$ \\
\hline 320 & $\bar{M}$ & $11 / 18 / 87$ & $\begin{array}{l}\text { A FIRE OCCURRED IN A ROOFING TAR PIT AT 320-M. THE FIRE OCCURRED WHEN THE } \\
\text { TAR KETTLE OVERHEATED AND IGNITED. THE FIRE WAS EXIINGUISHED BY AN } \\
\text { EMPLOYEE. NO DAMAGE. }\end{array}$ \\
\hline 320 & $\bar{M}$ & $7 / 9 / 86$ & $\begin{array}{l}\text { A FIRE OCCURRED IN BUILDING 320-M. THE FIRE WAS CAUSED BY A LITHIUM POT } \\
\text { EXPLOSION. THE FIRE WAS EXTINGUISHED BY THE FIRE DIVISION. DAMAGE } \\
\text { UNKNOWN AT THIS TIME. }\end{array}$ \\
\hline 320 & $\mathbf{M}$ & $6 / 20 / 80$ & $\begin{array}{l}\text { A FIRE IN 320-M INVOLVED LITHUM WASTE BENEATH A SAW. THE FIRE WAS } \\
\text { EXTINGUISHED BY AN EMPLOYEE. THE EXACT CAUSE OF THE FIRE IS UNKNOWN. NO } \\
\text { DAMAGE WAS SUSTAINED. }\end{array}$ \\
\hline 320 & $\bar{M}$ & $6 / 3 / 76$ & $\begin{array}{l}\text { A PIECE OF SCRAP MAGNESIUM IGNITED WHEN IT WAS ADDED TO MOLTEN METAL IN } \\
\text { AN AIR MELT FURNACE IN BUILDING 320-M. EXTINGUISHED BY AN EMPLOYEE. }\end{array}$ \\
\hline 320 & $\bar{M}$ & $7 / 1 / 75$ & $\begin{array}{l}\text { ALCOHOL, BENG USED AS A COOLANT IN AN ALUMINUM MACHINING OPERATION } \\
\text { IGNITED. EXTINGUISHED BY AN EMPLOYEE USING A FIRE EXIINGUISHER }\end{array}$ \\
\hline 320 & $M$ & $3 / 18 / 75$ & $\begin{array}{l}\text { ALCOHOL, USED AS A COOLANT IN MACHINING PARTS ON A LATHE, IGNITED IN } \\
\text { BUILDING 320-M. FIRE WAS EXIINGUISHED BY AN EMPLOYEE USING AN } \\
\text { EXTINGUISHER. }\end{array}$ \\
\hline 320 & $\vec{M}$ & $12 / 19 / 90$ & $\begin{array}{l}\text { A FIRE OCCURRED IN A DISTILLATION RANGE APPARATUS IN BULDING 320-M. THE } \\
\text { FIRE WAS CAUSED WHEN A FLASK CONTAINING DIESEL FUEL RUPTURED AND THE } \\
\text { DIESEL FUEL IGNITED. THE FIRE WAS EXTNNGUISHED BY AN EMPLOYEE. }\end{array}$ \\
\hline 320 & $M$ & $07 / 23 / 92$ & $\begin{array}{l}\text { The electrical coil wiring on a welding machine on the west side of the building shorted out and began } \\
\text { arcing, igniting oil on the breather of the welding machine. There were no injuries. Estimated damage } \\
\text { was } 550.00 \text {. }\end{array}$ \\
\hline 320 & $\bar{M}$ & $01 / 13 / 94$ & $\begin{array}{l}\text { In lab room 134, the flash point tester malfunctioned during testing, causing the paint that was used in } \\
\text { the testing to ignite and burn. The fire was extinguished by an employec using a } 10 \text { pound } A B C \\
\text { extinguisher at a cost of } \$ 80,00 \text {. There were no injuries. }\end{array}$ \\
\hline
\end{tabular}

\section{Page 18}

- 


\section{APPENDIX 1: DATA BASE FIRE EVENTS SINCE 1/1/1975}

\begin{tabular}{|c|c|c|c|}
\hline Facility & Area & 1 Date & Description of event \\
\hline 320 & $M$ & $12 / 19 / 90$ & $\begin{array}{l}\text { A FIRE OCCURRED IN A DISTILLATION RANGE APPARATUS IN 320-M. THE FIRE WAS } \\
\text { CAUSED WHEN A FLASK CONTAINING DIESEL FUEL RUPTURED AND THE DIESEL FUEL } \\
\text { IGNITED AFTER COMING IN CONTACT WTTH A HEATER COIL. THE FIRE WAS } \\
\text { EXIINGUISHED BY AN EMPLOYEE. DAMAGE S1,450.00. NO INJURIES. }\end{array}$ \\
\hline 321 & $\bar{M}$ & $11 / 13 / 85$ & $\begin{array}{l}\text { A FIRE OCCURRED INSIDE A BOX TRANSFORMER AT 321-M. THE FIRE WAS CAUSED BY } \\
\text { AN ELECTRICAL SHORT. THE FIRE WAS EXITNGUISHED BY AN EMPLOYEE. DAMAGE } \\
\text { UNKNOWN AT THIS TIME. }\end{array}$ \\
\hline 321 & $\bar{M}$ & $6 / 26 / 80$ & $\begin{array}{l}\text { A fire burned insulation and a timer on a welder in 321-M. The fire was caused by a short in the timer. } \\
\text { It was extinguished by an employee. Damages are estimated at } \$ 60.00 \text {. }\end{array}$ \\
\hline 321 & $M$ & $3 / 13 / 79$ & $\begin{array}{l}\text { A fire occurred in building } 321-M \text { when sparks from an overhead welding operation ignited oil in a } \\
\text { lathe pan. The fire was extinguished by an employee using a fire extinguisher. This was a construetion } \\
\text { fire. }\end{array}$ \\
\hline 321 & $\bar{M}$ & $2 / 9779$ & $\begin{array}{l}\text { A fire occurred in } 321-\mathrm{M} \text { machining room when alcohol, being used as a coolant, ignited during a core } \\
\text { sawing operation. The fire was extinguished by an employee using a fire extinguisher. There was no } \\
\text { damage. }\end{array}$ \\
\hline 321 & $\bar{M}$ & $1 / 31 / 79$ & $\begin{array}{l}\text { A fire occurred in } 321-\mathrm{M} \text { when alcohol, being used as a coolant, ignited during a core sawing operation. } \\
\text { The fire was extinguished by an emplovee using a fire extinguisher. }\end{array}$ \\
\hline 321 & $\bar{M}$ & $8 / 4 / 75$ & $\begin{array}{l}\text { Fire occurred in the electrical insulation on wiring to one of the casting furnaces. Extinguished with a } \\
\text { fire extinguisher. }\end{array}$ \\
\hline 321 & $\mathbf{M}$ & $10 / 9 / 89$ & $\begin{array}{l}\text { A fire occurred in oven area in building } 321-\mathrm{M} \text {. The fire was caused by an electrical short in the } \\
\text { transformer. The fire was extinguished by the fire department. Damage unknown. }\end{array}$ \\
\hline 321 & $\bar{M}$ & $02 / 20 / 92$ & $\begin{array}{l}\text { An electrical fire occurred when construction electricians energized a } .5 \text { KVA transformer during a } \\
\text { facility equipment tumover inspection. The fire was extinguished by the electricians. No injuries. } \\
\text { Damage estimated at } \$ 724.50 \text {. }\end{array}$ \\
\hline 773 & A & $5 / 24 / 88$ & $\begin{array}{l}\text { A fire occurred in a furnace in building } 773-\mathrm{A} \text { fab-lab. Lubricant was being heated to } 2000 \mathrm{C} \text {, when the } \\
\text { lubricant reached its flash point it ignited. The fire was allowed to self extinguish. }\end{array}$ \\
\hline 773 & $\bar{A}$ & $3 / 28 / 88$ & $\begin{array}{l}\text { A fire oceurred in building } 773-\mathrm{A} \text { B-070. The fire was started by sparks from a construction cutting } \\
\text { operation which fell into a pit and ignited plastic and plexiglass in the pit. The fire was extinguished by } \\
\text { a construction emplovee. No damage }\end{array}$ \\
\hline 773 & A & $5 / 20 / 85$ & $\begin{array}{l}\text { A fire occurred outside the fab lab at 773-A. The fire occurred when trash and rags on an energized } \\
\text { heat strip ignited. The fire was extinguished by an employee. No damage. }\end{array}$ \\
\hline 773 & $\bar{A}$ & $2 / 24 / 84$ & $\begin{array}{l}\text { A microwave oven caught fire in building 773-A. The inside top of the oven fell and ignited. The fire } \\
\text { was extinguished by an employee. }\end{array}$ \\
\hline
\end{tabular}

Page 19

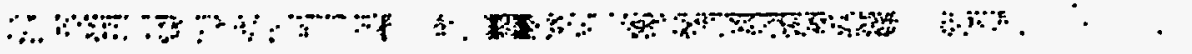




\section{APPENDIX 1: DATA BASE FIRE EVENTS SINCE 1/1/1975}

\begin{tabular}{|c|c|c|c|}
\hline Eacility & Ares & Date & Description of event \\
\hline 773 & A & $11 / 17 / 83$ & $\begin{array}{l}\text { A fire occurred in the decon and disassembly facility in F-wing } 773-A \text {. The fire was caused by a welder } \\
\text { burning operation. A metal box was being cut up for disposal when a nubber glove ignited. The fire } \\
\text { was extinguished by the halon system. }\end{array}$ \\
\hline 773 & $\bar{A}$ & $9 / 7 / 83$ & $\begin{array}{l}\text { A fire oecurred in a computer cabinet in building 773-A when a routine load test was being made and } \\
\text { some insulation bumed. The cause has not been determined. The fire was extinguished with a } \mathrm{CO} \\
\text { extinguisher. Damage has been estimated at between } \$ 500 \text { and } \$ 1000\end{array}$ \\
\hline 773 & A & $3 / 28 / 83$ & $\begin{array}{l}\text { A fire oceurred in 773-A. A welder was cutting floor grating when the slag ignited brimstone floor } \\
\text { sealant used for sealing floor tiles. The fire was extinguished by the employee. No damage was } \\
\text { sustained }\end{array}$ \\
\hline 773 & $\overline{\mathbf{A}}$ & $12 / 10 / 81$ & $\begin{array}{l}\text { A fire oceurred inside a fluorine cylinder containment cabinet located in } 773-\mathrm{A} \text {. The exact cause of the } \\
\text { fire has not been determined but the fire is known to have started in a flow limiting valve and eventually } \\
\text { caused the cylinder to nupture. The fire self-extinguished. }\end{array}$ \\
\hline 773 & A & $10 / 17 / 80$ & $\begin{array}{l}\text { A fire bumed an electric motor on a photo enlarger in the } 773-\mathrm{A} \text { print shop. The fire apparently started } \\
\text { as a result of a short in the motor. It was extinguished by an employee. }\end{array}$ \\
\hline 773 & A & $6 \longdiv { 2 6 7 9 }$ & Fire occurred in a glove box in 773-A. Cause of fire is unknown. Was extinguished by an emplovee. \\
\hline 773 & A & $11 / 15 / 77$ & Fire occurred in a trash can. Cause unknorn. \\
\hline 773 & $\bar{A}$ & $8 / 16 / 77$ & $\begin{array}{l}\text { Building 773-A, laboratory C-111. A sample was being prepared for etching. A spark was created from } \\
\text { use of methvl alcohol. }\end{array}$ \\
\hline 773 & A & $2 / 10 / 76$ & $\begin{array}{l}\text { Feed preparation box of the sed-i facility in 773-A. A metal can containing a defective nibber glove } \\
\text { was inadvertently placed on the electrical coil to an induetion fumace. A small bole rwas bumed in the } \\
\text { can and ignited the glove. }\end{array}$ \\
\hline 773 & $\bar{A}$ & $3 / 31 / 75$ & $\begin{array}{l}\text { Welding sparks ignited insulation in the fan room of the high level cave area of } 773-A \text {. The fire ivas } \\
\text { extinguished with a fire extinguisher and water from the fire department pumper. }\end{array}$ \\
\hline 773 & A & $10 / 7 / 88$ & $\begin{array}{l}\text { A fire occurred in building } 773-A \text {. The fire bumed paper and plastic. The fire was caused by hot slag } \\
\text { from a cutting operation. The fire was extinguished by an employee. }\end{array}$ \\
\hline$\overline{773}$ & A & $08 / 08 / 90$ & $\begin{array}{l}\text { A fire occurred in a glove box in building 773-A. The fire was caused when a polyurethane bottle came } \\
\text { in contact with a hot plate. The fire was extinguished by the fire departmert. }\end{array}$ \\
\hline
\end{tabular}

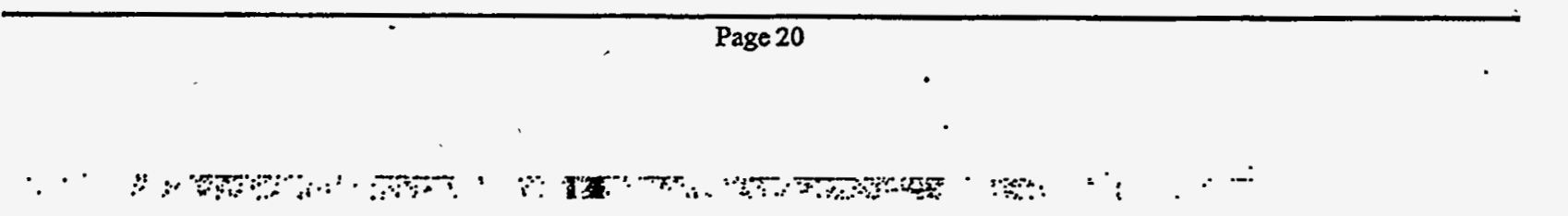


WSRC-TR-95-0389: Revision $0^{-}$

\section{APPENDIX 2: DATA BASE FIRE EVENTS SINCE 1/1/1975}

\begin{tabular}{|c|c|c|c|}
\hline Eacility, & Ares & Date & Description of eyyent \\
\hline 221 & $\mathbf{F}$ & $6 / 2 / 88$ & $\begin{array}{l}\text { A FIRE OCCURRED AT THE EMERGENCY GENERATOR ROOF SOUTH END OF 221-F. THE } \\
\text { FIRE WAS CAUSED WHEN A PIECE OF HEMP ROPE LEFT BY CONSTRUCTION BY } \\
\text { GENERATOR STACK HEATED FROM THE STACK AND IGNITED. THE FIRE WAS } \\
\text { EXTINGUISHED BY THE FIRE DIVISION. }\end{array}$ \\
\hline 221 & $\bar{F}$ & $7 / 24 / 87$ & $\begin{array}{l}\text { A FIRE OCCURRED IN } 221 \text {-F FIRST LEVEL COMPRESSOR ROOM SOUTH END. BELTS ON } \\
\text { COMPRESSOR OVERHEATED AND IGNITED. THE FIRE WAS EXITNGUISHED BY THE FIRE } \\
\text { DIVISION. DAMAGE UNKNOWN AT THIS TIME. }\end{array}$ \\
\hline 221 & $F$ & $7 / 28 / 85$ & $\begin{array}{l}\text { A FIRE OCCURRED IN } 221 \text {-F A-LINE. OIL IN THE DENITRATOR OVERHEATED AND } \\
\text { IGNITED. THE FIRE WAS EXTINGUISHED BY THE FIRE DIVISION. NO DAMAGE. }\end{array}$ \\
\hline 221 & $\mathrm{H}$ & $1 / 30 / 80$ & $\begin{array}{l}\text { A NEW PLASTIC BAGGED HEPA FILTER WAS PLACED IN } 221 \text {-H LNNE RECOVERY } \\
\text { CABINET. INADVERTENTIY, THE FILTER WAS PLACED ON A HOT DISSOLVER, WHICH } \\
\text { IS BELIEVED TO HAVE IGNITED THE PLASTIC BAG. AN AUTOMATIC HALON SYSTEM } \\
\text { EVENTUALLY EXTINGUISHED THE FIRE. TWO CABINET WINDOWS WERE CRACKED. } \\
\text { NO CONTAMNATION RELEASE TO ATMOSPHERE, VERY LTTLE IN ROOM. }\end{array}$ \\
\hline 235 & $F$ & $10 / 5 / 89$ & $\begin{array}{l}\text { A FIRE OCCURRED IN BUILDING } 235 \text {-F PLUTONIUM EXPERIMENTAL FACILITY. THE FIRE } \\
\text { WAS CAUSED WHEN A VACUUM PUMP MOTOR BURNED OUT. THE FIRE WAS } \\
\text { EXITNLUISHED WHEN THE HALON SYSTEM WAS ACTIVATED. }\end{array}$ \\
\hline 320 & $\mathbf{M}$ & $7 / 9 / 86$ & $\begin{array}{l}\text { A FIRE OCCURRED IN BUILDING } 320-M \text {. THE FIRE WAS CAUSED BY A LITHIUM POT } \\
\text { EXPLOSION. THE FIRE WAS EXINGUISHED BY THE FIRE DIVISION. DAMAGE } \\
\text { UNKNOWN AT THIS TIME. }\end{array}$ \\
\hline 321 & $\bar{M}$ & $10 / 9 / 89$ & $\begin{array}{l}\text { A FIRE OCCURRED IN OVEN AREA IN BUILDING 32I-M. THE FIRE WAS CAUSED BY AN } \\
\text { ELECTRICAL SHORT IN THE TRANSFORMER. THE FIRE WAS EXTINGUISHED BY THE } \\
\text { FIRE DEPARTMENT. DAMAGE UNKNOWN. }\end{array}$ \\
\hline 773 & $\bar{A}$ & +147483 & 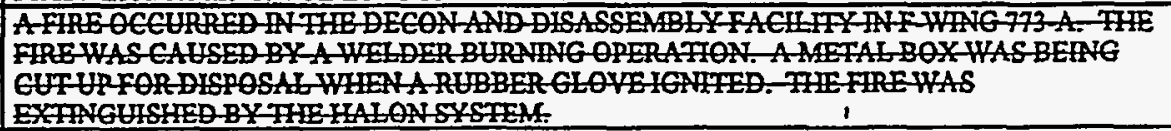 \\
\hline 773 & $A$ & 373475 & 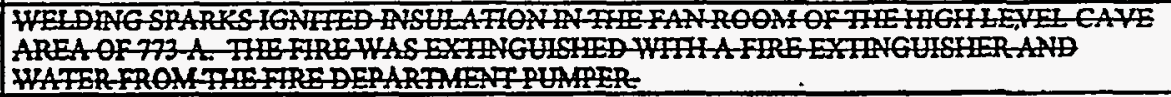 \\
\hline 773 & $\bar{A}$ & $08 / 08 / 90$ & $\begin{array}{l}\text { A fire occurred in a glove box in brilding } 773-\mathrm{A} \text {. The fire was caused when a polyurethane bottle came } \\
\text { in contact with a hot plate. The fire was extinguished by the fire department. }\end{array}$ \\
\hline
\end{tabular}

Page 21

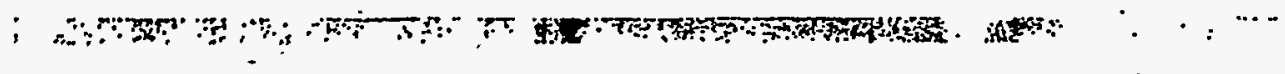

